\title{
The Krupp-Renn Process
}

in Czechoslovakia

\section{Based on an article}

submitted by the Czechoslovakian Delegation to the Steel Committee of the Economic Commission for Europe, and

\section{I}

N Czechoslovakia there are deposits of highly acid 1 iron ores, averaging some 28 pct Fe and 25 pct $\mathrm{SiO}_{2}$. The alumina content is some 8 pct, while basic components, such as $\mathrm{CaO}$ and $\mathrm{MgO}$, are found only in negligible quantities. Because of the excessive quantities of coke and limestone required, such ores cannot be economically treated by traditional blast furnace technique.

Numerous beneficiation experiments have been conducted on these ores, but due to their strongly striated structure, with the iron and silica chemically combined, the results have been poor. To process these ores a Krupp-Renn installation was, thus, laid down in Czechoslovakia. It does not differ greatly from plants previously constructed in Korea, Japan, and at Watenstedt in Western Germany.

A brief outline of the process is as follows: Ore, reduced to $25 \mathrm{~mm}$, is blended to 27 pct of its weight with powdered coke of $5 \mathrm{~mm}$ or less. These are mixed into a homogeneous mass and charged into the Krupp-Renn furnace, a rotary kiln, 3-m interior diam and $60-\mathrm{m}$ long. It revolves once every 52 seconds. The furnace is fired with pulverized coal with a heating value of $6000 \mathrm{Kcal}$. Fuel requirements amount to some 7 pct of the weight of the charge. The burners are located at the exit end of the furnace where the temperature is maintained between $1300^{\circ}$ and $1400^{\circ} \mathrm{C}$. The combustion gases traverse the furnace and leave at the charging end to enter a dust collector at about $450^{\circ} \mathrm{C}$.

The charge moves through the furnace by means of the rotation and the 2 pct inclination. It is dried and preheated to $500^{\circ} \mathrm{C}$ by the time that it has traversed one third of the furnace. At this point reduction commences and continues until the ore is discharged; however, the greatest reduction takes place in the central portion of the furnace where the temperature is between $600^{\circ}$ and $1000^{\circ} \mathrm{C}$. With mounting temperature minute particles of iron form in the charge, and the mass is transformed into a pasty substance. The particles of deoxidized iron coagulate under the rotating action and appear in the form of grains of variable dimensions, but generally not exceeding $10 \mathrm{~mm}$. This slaggy mixture passes out the furnace and into a pan conveyor which carries it to the storage area. The mixture of Krupp-Renn iron grains and slag cools for about two days and is then transferred by clam shell bucket to the grinding department.

The cooled slaggy mass is ground in a ball mill to liberate the grains of iron from the slag, and this is followed by screening and separation by electromagnetic cylinders. Iron grains larger than $0.8 \mathrm{~mm}$ are for blast furnace charging, while the finer material, which contains almost 60 pct $\mathrm{Fe}$, is returned to the Krupp-Renn furnace.

\author{
Published in \\ Advances in Steel Technology in 1955 by the United \\ Nations in Geneva, Switzerland
}

The present Krupp-Renn process has, in addition to its many advantages, a certain number of serious defects, which explain why the process is not more widely used at present. The following are the advantages:

1) It does not require metallurgical coke, but instead makes use of fuel and reducing medium of inferior quality, with the exception of pulverized coal for the furnace fuel. The latter is used only in small quantity and may be replaced by other combustibles.

2) The iron-slaggy material is readily separated into iron grains containing between 88 and 90 pct $\mathrm{Fe}$ and less than 5 pct $\mathrm{SiO}_{2}$.

3) The remelting and desulfurization of the grains in a blast furnace requires only $300 \mathrm{~kg}$ of coke per metric ton charged.

4) For acid ores the over-all cost of production of pig iron obtained by the Krupp-Renn process is well below that obtained by direct reduction in a blast furnace.

5) The Krupp-Renn process permits the utilization of ore fines without recourse to sintering.

The principal disadvantages of the process are: 1) high capital expenditure; 2) bad working conditions caused by large quantities of dust released in processing the Krupp-Renn iron grains; and 3) high production costs in spite of point 4 , above.

Metallurgists are cognizant of these facts, and with the construction and operation of some new plants, they hope to gain further experience in this process. The Department of Research has already embarked on a research program designed to simplify and improve the over-all Krupp-Renn process, reduce capital expenditures, and accelerate the operation. Semi-commercial installations are being constructed, and two modified techniques have emerged from this project. The first consists of reducing the hot mass leaving the furnace to grain size by means of a current of water on the cooling belt and following this by electromagnetic separation. The second method consists of utilizing a low shaft furnace to treat the hot product of the KruppRenn kiln, raising the temperature of the mass until the slag and metal separate by difference in density.

In addition, studies will be undertaken regarding the best means of utilizing the gases forming in the interior of the furnace to preheat the combustion air for the burners. Finally, trials will be made on the utilization of fuels for which there is no other use.

Positive results from these experiments should permit the realization of substantial progress on the road to the more economic exploitation of the KruppRenn process. 